\title{
The identity of hybrid dance artist-academics working across academia and the professional arts sector
}

\author{
Sally Doughty and Marie Fitzpatrick \\ De Montfort University
}

\begin{abstract}
This article reports on interim findings from an evolving research project that sets out to examine and document the experiences of hybrid dance artist-academics working across academia and the professional arts sector. Three round table events and an online conversation enabled the capturing of voices of those who operate in academia and the professional arts sector in response to the research project's three main aims:
\end{abstract}

- To understand the experiences of the hybrid dance artist-academic

- To shed light upon the contextual factors that shape these experiences

- To offer recommendations that may support a productive, creative practice environment for the hybrid dance artist-academic.

This article further contextualizes commentaries within wider discourse on artistic practice and/or Practice as Research (PaR), such as those from Practice as Research in Performance (PARIP) and the Centre for Research into Creation in the Performing Arts (ResCen). The relationship between arts-making practices and neo-liberalist frameworks is explored. The emergent issues of hierarchies, dissidence and the epistemology of the hybrid dance artist-academic are presented and conceptions of agency and community are reconsidered. 


\section{Keywords}

dance artist-academic

the academy

professional sector

hierarchies

identities

creative practice

This article reports on interim findings from an evolving research project that sets out to examine and document the experiences of hybrid dance artist-academics working across academia and the professional arts sector. It focuses upon practitioners' experiences of working practices and environments set in this specific context. However, project findings have relevance for those engaged in movement and choreographic practices that can resonate more broadly.

Over the past decade or so, there has been a particular increase in independent dance artists migrating into more formal positions within the Academy. Indeed, it has been noted that independent artists may seek refuge in the Academy (Bailie 2003), which suggests that higher education can offer a safe and supportive environment in which artists can develop their practice, alongside earning a regular income (Reynolds 2003). The principal investigators of this research project joined the Academy from professional dance artists' backgrounds and their personal experiences of working across academia 
and the professional arts sector, coupled with an increasing awareness of the status of other dance artists working across both contexts, initially prompted this research project.

The project was launched at The Inventing Futures Symposium, Arnhem (2013), ${ }^{1}$ with two further events at the Questioning the Contemporary in 21st Century British Dance Practices Symposium (2014) ${ }^{2}$ and at Artists in Academia: Conflicts and Contributions (2014). ${ }^{3}$ Each event comprised small focus groups or 'round tables' and attracted between 31 and 70 participants, all of whom are involved in dance as either dance artists, dance lecturers, scholars, dance artist-academics and/or s, the latter of which are defined as 'brokers who mediate between artists and audiences....as coproducer, as tastemaker, and as selector' (Foster et al. 2011: 248). However, we suggest this definition of a gatekeeper or broker does not accurately reflect the collaborative exchange that can occur between one or more parties. More recently the principal investigators engaged in an online conversation with curator/programmer Jane Greenfield and artist/curator Frank Bock, as part of Dance 4's NottDance Festival 2015. ${ }^{4}$ Each event was designed to capture the participants' personal experiences in response to the research project's three main aims, which are:

- To understand the experiences of the hybrid dance artist-academic

- To shed light upon the contextual factors that shape these experiences

- To offer recommendations that may support a productive, creative practice environment for the hybrid dance artist-academic. 


\section{Context}

Dance artists working in higher education are not new phenomena, and whilst models for the artist-academic were established in the United States as early as the 1930s, the idea is still of quite recent origin in the United Kingdom. Tensions have existed in the United Kingdom for the last 40 years or so between academia, ${ }^{5}$ from which artistacademics more traditionally evolve, and institutions concerned more with professional training. Contemporary discussions about the role and status of the artist-academic compared to that of the professional dancer who is not necessarily engaged in what is deemed academic research are rooted in a history that has as much currency today as it had in the twentieth century (Huxley 2015). Indeed, Jane Greenfield observes that whilst there have been tensions between the professional and academic areas with a clash of interests and questions around status for those working inside and beyond academia, there has recently been much more interchange between the two (2015).

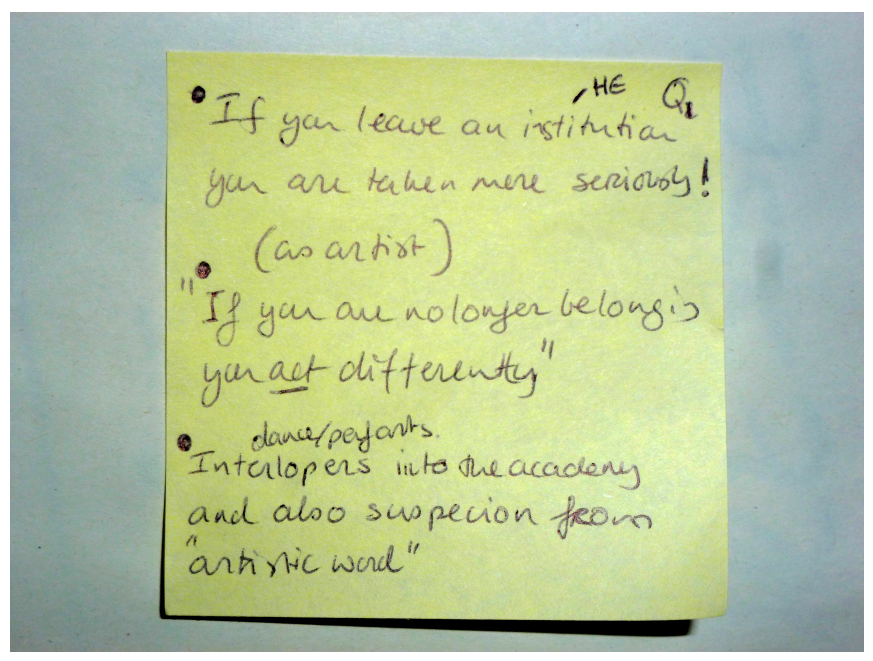

Figure 1: Anonymous participant 2014 
Whilst there is a burgeoning literature that addresses the current status and position of artist-academics, this is largely in relation to subjects other than dance (Shreeve 2011; Tondeur 2013; Daichendt 2011). Little has been published that addresses the context specifically for the dance artist-academic although there is evidence of conference debates about the role of the artist-academic taking place for over a decade. In 2003, Christopher Bannerman made the observation that synergies between arts practice and universities had been developing for more than twelve years (2003) and he goes on to refer to practitioners migrating into the Academy as 'new scholars' (2003), recognizing that new territory was opening up as an outcome of the developing relationships between arts professions and universities (2003). Whilst Bannerman refers to the synergies arising from the links between both contexts, he does not refer to the potential tensions that exist for artist-academics operating between both these worlds. Alison Shreeve observes that 'the relations experienced between professional practice and academic roles can be indicative of adjustments and turmoil in identities' (2011: 80) and Louise Tondeur further supports this when she notes that 'artists outside academia don't have to define themselves in the same way as those working within it' (2013). Shreeve's 'adjustments and turmoil in identities' (2011: 80) are pronounced because the boundaries between dance artists working in academia and the professional arts sector have indeed blurred over the last decade or so. Dance artists working within academia may seek to maintain a practice-based profile within the professional arts sector, and an increasing number of professional dance artists are seeking links with academia through employment, postgraduate or doctoral study and by default their practice is often defined as Practice as Research (PaR), which has been a subject of much interest over the last decade. 
Practice as Research in Performance (PARIP) was established in 2001 to 'investigate creative-academic issues raised by practice as research' (PARIP overview) with an overarching aim to 'develop national frameworks for the encouragement of the highest standards in representing practical-creative research within academic contexts' (PARIP overview). Whilst PARIP addressed important issues pertaining to PaR undertaken within academic contexts, it also tackled how PaR problematizes notions of 'professional' and 'academic' practices (PARIP 2003), which was a theme of the 2003 PARIP national conference. This suggests that tensions existed for dance artist-academics working across academia and the professional arts sector and it is interesting to note that many of the key observations raised at the conference over a decade ago are still relevant today. The issues, tensions and synergies that are commonplace in today's contemporary context are reflected in the initial findings arising from this research project and are discussed in a later section.

Working methods relevant to PaR have been documented and are the focus of much discourse about artistic practice within academia (PARIP 2001-2006; ResCen 1999-; Nelson 2013; Barrett and Bolt 2014). The Centre for Research into Creation in the Performing Arts (ResCen) was established in 1999 as a "bridge between academia and the practices of professional performing artists' (ResCen home) and is concerned with the ways in which the working artist, under the usual pressures of the arts marketplace, can be enabled to create, reflect, disseminate and contribute to the arts nationally and internationally (ResCen home), and can be said to be continuing with the work and research that was established by PARIP. Whilst there is much documentation on the 
creative processes and working methods of the six research associate artists supported by ResCen, a gap in the literature has been identified by this project. That is, the experiences of those who are engaging in artistic practice across both academic and professional arts contexts are not made visible and it is these personal experiences that underpin this research.

It is necessary to make the point here that artists working outside of academia may not necessarily refer to their activities as PaR or artistic research: an artist's work may be categorized as personal practice, pedagogic practice or artistic investigations. Personal experience and initial research findings demonstrate that artists who are aligned with the Academy and who are, by default, deemed to be engaging in academic research (which includes PaR) may find it increasingly difficult to position themselves as artists beyond an academic context. At the PARIP national conference 2003 it was suggested that PaR develops 'advanced research that the industry doesn't necessarily want to do' (Anon. 2003) and Jane Greenfield notes that in the past, programmers questioned whether work made by dance academics was,

good enough; is it going to stand up in the programme alongside the other work; is it going to be of a similar kind of quality; is it going to have the same production values, is it going to be of interest to my audience? (2015)

It is apparent that this view still has currency today: at the Questioning the Contemporary in 21st Century British Dance Practices symposium, producer Claire Hicks referred to creative practice coming out of the Academy as being too reflexive and academic (2014) to have a place in the professional sector. These examples support the experiences of some artist- 
academics who are endeavouring to work across both academia and the professional arts sector. Shreeve reports that those who are operating successfully have conceived of their working environments as 'two separate cultural worlds' (2011: 80), which suggests that their practice is largely shaped and defined by the discrete framework within which they operate.

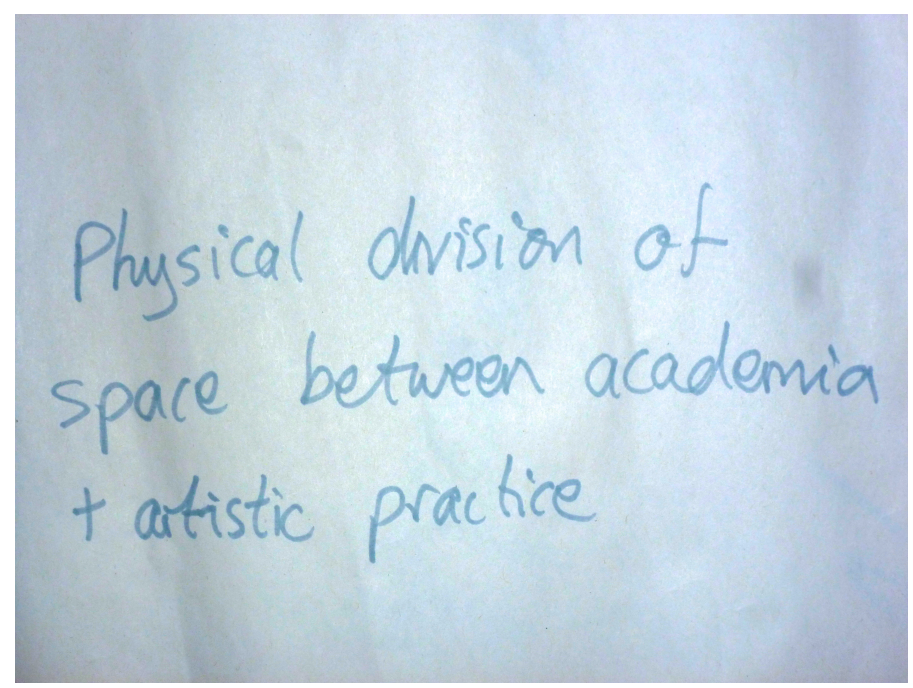

Figure 2: Anonymous participant 2014

Many of these project's findings so far certainly conform to this notion of a binary experience although artists are attempting to work in ways that are multiple and fluid, and in what might be described as a liminal space between the two.

\section{Terminology}

The multiplicity of activities and environments in which an artist, academic, researcher, teacher, practitioner, choreographer and scholar may engage is reflected in the broad ranging terminology that is used to define their identity. Daniel (2010), Daichendt (2011), Piccini and Kershaw (2004) amongst others, refer to the 'artist-scholar' to articulate more than one identity. PARIP refers to 'creative-academics' (PARIP 
overview) and ResCen refers to artist-researchers (ResCen centre). Identifying a suitable term to define colleagues working across academia and the professional arts sector for the purposes of this research project has been challenging, semantically. Findings thus far suggest that terms such as 'artist-scholar' or 'artist-academic' are highly problematic in that they suggest a binary positioning and promote a differentiation of one activity or one set of knowledges from another. Therefore, these terms do not accurately reflect the nature of what most artist-academics do which is indeed multiple, synergetic and fluid. Acknowledging these limitations and issues with terminology we propose the term hybrid dance artist-academic to reflect the multiplicity of activities and worlds that those involved in both academia and the professional arts sector inhabit. We suggest that another, more liminal space that is non-linear and fluid evolves out of the hybridity of experience that overlaps both worlds.

\section{Methodology}

The research design evolved in direct response to the primary thrust of the project, which is reliant upon collecting personal experiences and opinions from people involved in dance in higher education and the professional arts sector. The three round table events held were based on the World Café methodology that supports participants coming together in a large group dialogue in a simple, effective and flexible format (theworldcafé). An informal and relaxed environment was engendered so that participants felt able to contribute openly about their experiences and to learn from each other. The round tables facilitated small breakout discussion groups of between four and nine participants in each, in which they discussed interview type questions. Whilst these 
questions have been refined as the project has developed, their thrust has not changed. Questions posed at the last round table (September 2014) are as follows:

- Are there synergies, tensions and opportunities that exist (for hybrid dance artistsacademics) working across academia and the professional arts sector?

- In your experience what are the conditions that dictate these synergies, tensions and opportunities?

- Are potential trajectories of artistic enquiry/research in the Academy and the professional arts sector in/compatible?

- What does a productive, creative practice environment look and feel like for the hybrid dance artist-academic who operates in the liminal space between academia and the professional arts sector?

In the first two round tables, we did not participate in the small group discussions, electing instead to move from group to group and 'listen in' from a distance. We were mindful that our presence in the groups might engender a biased response from the other participants which can be a hazard when engaging in ethnographic methods, and particularly so when engaging in research activities that rely on discourse about personal experience. However, for the last round table event we decided to be more directly involved in the discussions. Anselm Strauss and Juliet Corbin stress that 'the touchstone of your own experience may be [...] an indicator for you of a potentially successful 
research endeavour' (1990: 35-36) and as we are both practicing hybrid dance artistacademics we decided that bringing our own voices to the table could make a meaningful contribution to the unfolding discussions. Traditionally, personal interjection into the research could be treated as biased but, if considered in a critically subjective way, this valuable experiential data (Strauss 1987) can also contribute a major source of insights, hypotheses and validity checks (Maxwell 2008: 225). On reflection, it is certainly the case that we share very similar experiences to those voiced by other participants.

A great deal of data were generated through these discussions and captured through participants' own note taking and audio recordings at each round table. Transcriptions of audio-recordings guided our identification of any special features that might occur (O’Toole 2006: 44) which were aligned to the participants' own written notes, and qualitative research methods supported us in 'collecting and analyzing data, developing and modifying theory, elaborating or refocusing the research questions' (Maxwell 2008: 215).

Recurring characteristics that were evident in the transcriptions from the first two round tables encouraged us to reconsider the design of the discussion questions that were used to facilitate the third round table. For example, as discussed earlier, a common feature was that the language used to describe the role of the artist-academic was problematic and therefore we clarified this for the delivery of our third round table event. Progressively reframing and focusing the discussion questions allowed us to integrate findings as they arose into the developing research. More recently, the Dance 4 online 
conversation allowed us to select key findings from the discussions and use these as a framework for debate with colleagues involved in curating and programming.

\section{Interim findings}

Interim findings so far have illuminated two emergent areas that can be synthesised as 'frameworks, hierarchies and dissidence' and the 'epistemology of dance practices'.

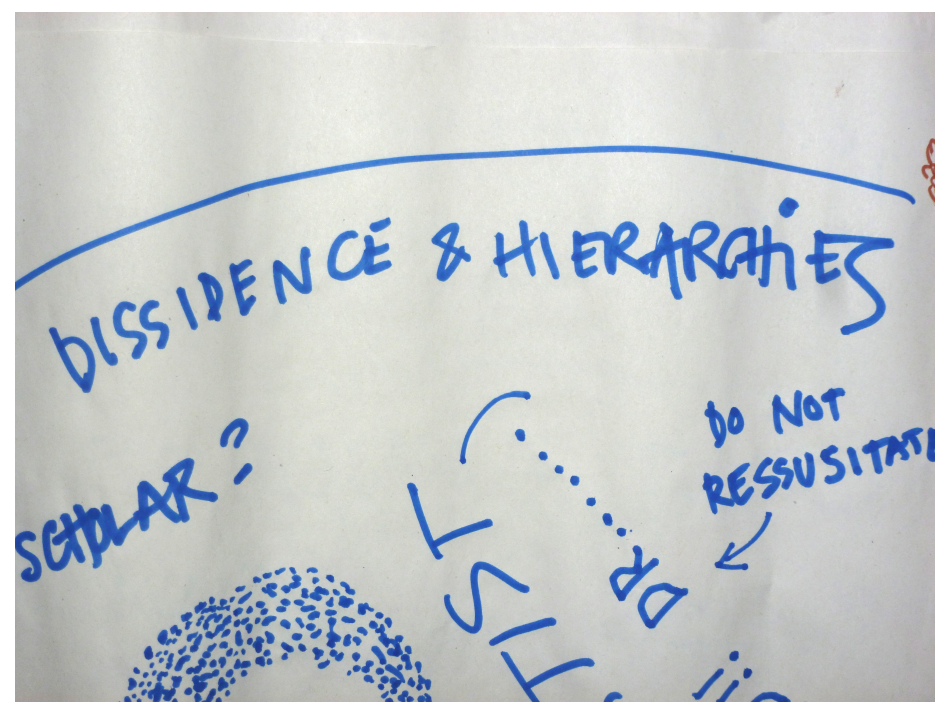

Figure 3: anonymous participant 2014
A key theme that arose from round table discussions centres on the frameworks that the artist, academic or gatekeeper operates within. Discussions tended to focus more on the experiences encountered within the Academy as opposed to the professional arts sector, however, that in itself reflects the balance of representation of round table participants who work in the Academy and where the focus of concern is for many of these participants. The Dance 4 online conversation enabled us to draw upon observations from those in programmer/curator roles in the professional arts sector. 


\section{Frameworks, hierarchies and dissidence}

The 'vertical hierarchy' of the Academy was cited as being at odds with the more 'open and circular way of exchanging' (Anon. 2014) ${ }^{6}$ that the dance community has more historically operated within. Notions of a horizontal way of exchanging or a horizontal community were put forward not only as the pre-existing and current experience for dance artists and academics networking with other peers, but as a conscious proposition for survival within Academy structures in particular (Anon. 2014).

Those involved in PaR, creative and/or pedagogic practices noted a tension in the navigation of Academy structures that are aligned with more traditional scholarly activities and research outputs. In addition to this, commentaries alluded to the 'star' artist or academic who attracts funding and reinforces a sense of verticality in the hierarchy of the institution. This suggests a current cultural shift in how performancebased subjects within the Academy are adapting in order to succeed in a competitive Higher Education (HE) market.

Artistic practice can be difficult to justify at a mid-level rhetoric. When you get past that ceiling there's a different kind of conversation and understanding. At a high level of research in the Academy, it's particular kinds of artists, those with an international profile and lots of money that become the players of the research projects. All these contextual frameworks are shaping the synergies and conditions. The landscape has changed. (Anon. 2014) 
The combination of artist and scholar assumes a divide. The Academy reinforces this. People have got their careers, their niches, their fetishes and it's staying there. (Anon, 2014)

The professional arts sector, however, is not necessarily free of hierarchical concerns. In his book, Cultural Capital: The Rise and Fall of 'Creative Britain', Robert Hewson states that a cultural crisis is looming as the arts are becoming overly reliant on Lottery funding in light of ongoing austerity cuts and the restructuring and centralizing of local authorities and key organizations such as Arts Council England (ACE) (2014). He argues that the emergence of the creative industries, entrepreneurism and the ties between economy, politics and cultural growth fostered by the New Labour government in 1997 has engendered a neo-liberal product /consumption model where the arts have been reconfigured and situated within economic frameworks. Hewson proposes that the commercialization of the production of culture has shaped the very nature of creativity by reducing art-making practices to commodification.

The tension between the rhetoric of funding bodies that are positioned within such frameworks and the relationship of the creative practitioner with such funding bodies is a sentiment echoed at round table discussions. Commentaries allude to a disparity of how dance as an art form sits within a product/ consumption model where the outcome is prioritized very prominently within funding criteria. For example; one participant stated 'ACE demands so much of the outcome and you can't make decisions about the outcome and as soon as you start doing that you destroy the nature of creativity. On the other hand 
it's public money [but] performance cannot operate in a product/consumption model' (Anon. 2014).

The issue of public money has been raised in a recent speech given by the Chair of ACE, Sir Peter Bazalgette, in which he proposed a fundamental shift in ACE's approach to diversity. He cites Indhu Rubasingham, Director at Tricycle Theatre as saying 'If you don't represent your community, how is your work authentic? And if you don't engage with the taxpayers, why should they fund you?' (Rubasingham in Bazalgette 2014). Whilst Bazalgette cites this observation as an example of how arts organizations must responsibly reflect their communities, the same could be said for the Academy. If artistic work that is developed within an academic context has minimal exposure in communities beyond the Academy, then it follows that there could be a lack of understanding and support for the work of the hybrid artist-academic in the professional arts sector. Sharing their work in a range of public contexts would help to dispel the elitist reputation that still exists for scholars of any discipline and promote universities for the public good. In 2008, The Higher Education Funding Council for England (HEFCE) highlighted that 'Universities and colleges are increasingly a source of knowledge and expertise for a very wide range of economic and social activities. Some of the top sectors to benefit are: Creative and Cultural' (HEFCE 2008), but if there is resistant to programming artistic research undertaken in academia because ' $\mathrm{PaR}$ is an area which does advanced research that the industry doesn't necessarily want' (Anon. 2003) then this limits the opportunities available to hybrid artist-academics to share their practice beyond academic contexts. It has been proposed that the Academy needs to get 
out into theatres and take PaR into the professional world (Anon. 2003) and indeed, there are models of very established and interconnected relationships between universities and arts organizations that are mutually beneficial. For example Dance 4, the dance development agency for the East Midlands, has a long history of supporting the work of hybrid artist-academics from De Montfort University and University of Northampton in a range of ways, including offering funding for projects and performance opportunities.

Reflecting upon their respective experiences in the professional arts sector, both Bock and Greenfield note that there has been a shift in the aesthetics of dance as an art form where dance is no longer just confined to performance orientated work made for a public audience. This is described as a conceptual turn in dance that identifies with some European artistic practice and brings with it a sense of intellectual enquiry, which is exemplified in the work of UK artist Jonathan Burrows (2015). Greenfield observes that

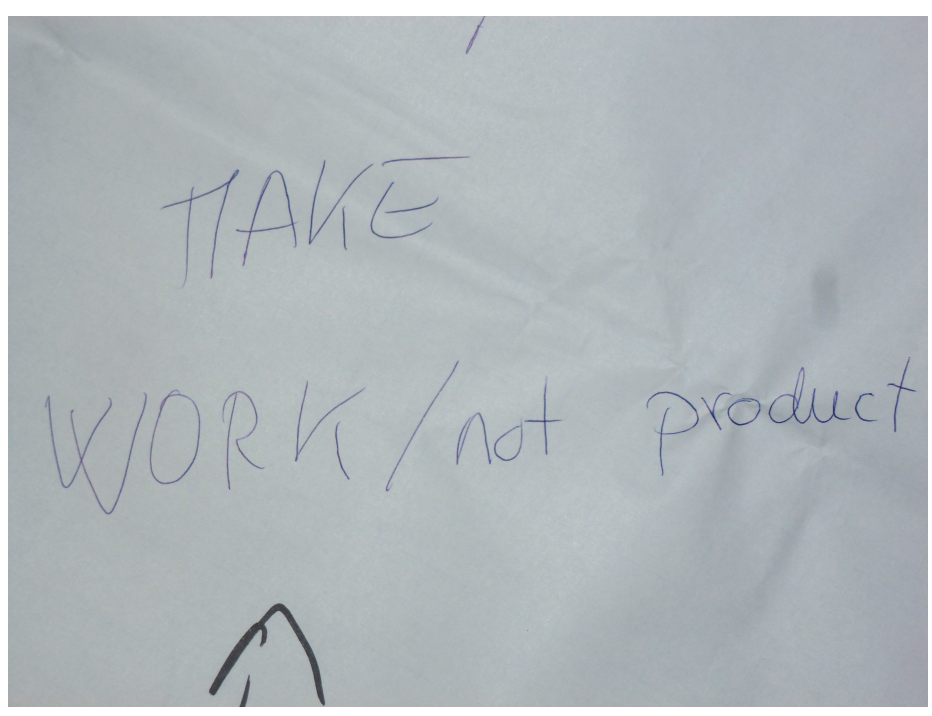

Figure 4: anonymous participant 2014 festival and venue programmes

have become more sophisticated and broader in range than they used to be. For example, programmes may now include research and development, process orientated enquiry alongside more traditional forms of finished performance work. 
The NottDance Festival, Nottingham and the What Festivals hosted by Independent Dance, originally instigated by Gill Clarke and currently curated by Frank Bock are pertinent examples of such a broad and diverse approach to programming. These programmes embrace an array of interrelationships with other disciplines and forefront the value of dialogue and process with its audiences and participants alike (What If 2010, What Now 2011, What Matters 2012, What Now 2013, 2014). Indeed, some whose work has featured in these festivals, such as Katye Coe, Simon Ellis, Vida Midgelow, Nicola Conibere, Marie Fitzpatrick and Sally Doughty can be identified as working across both the Academy and the professional arts sector and could be termed hybrid dance artist-academics.

Bock observes that 'Dance has become an expanded art form and that the relationship between philosophy and the art form sits very comfortably within the Academy' (2015). Greenfield concurs that this now expanded field of practice has helped to 'broker the relationship between academics, dancers and everything in between' (2015). This suggests that the ground is fertile for the sharing of practice, research and/or enquiry developed in academic contexts in a range of settings that exist beyond the Academy and that the development of the art form is a catalyst for such potentialities. The NottDance and What festival programmes are examples of this potential, but we suggest that these are the exception rather than the norm.

At the 2003 PARIP national conference it was predicted that the Academy was likely to be seen as a new commissioning body (Bailie 2003), as the belt on funding for 
the arts was being pulled increasingly tighter. Indeed, funding applications to, for example, ACE are strengthened by evidence of support from the Academy to host performances and workshops, and our experience of an increasing number of requests from dance artists and producers seeking such opportunities is shared by colleagues from across the sector and articulated by one participant who stated that 'there is a growing awareness of the means and the embracing of practice being funded through research channels. Most artists will look for funding at the Academy' (Anon. 2014).

If, as Hewson suggests, the cultural frameworks of the professional arts sector governed by the drive for commodification are becoming more heavily reliant on Lottery funding and are driven by the market forces and economic model of neo-liberalism, then this mirrors the hierarchy of the 'star' artist-academic currently coming to prominence across the HE marketplace. The drive to develop four star research, which is defined as 'quality that is world-leading in terms of originality, significance and rigour' (REF2014) can be aligned to perceived, marketable products of quality that guarantee an upper hand in the marketplace.

The relationship between neo-liberalism and the arts is further explored by Jyotsna Kapur who states:

Understanding this relation in the broader context of deepening capitalistic relations of exploitation, commodification, and abstraction can help explain the Faustian bargain that 21st century capitalism has imposed on the arts. While the arts get a new pre-eminence in public life, they have been completely subordinated to the market. In other words, they get a new lease 
on life but lose their soul. By turning the arts into a purely commercial enterprise, neo-liberalism has attacked the very core of artistic expression. Art relies on a sense of imagination, resistance, and community that underlies it and exceeds the rules of the market. (Kapur 2011)

The importance of the role of imagination, resistance and community as cited by Kapur was pervasive across all round table discussions and is further echoed by Jonathan Burrows who observes that 'we're raised in an art form whose value is not financial and that gives us a unique perspective on the world and we should celebrate that. And we should be proud that we deal in a currency of togetherness which is rarely cut throat' (2015).

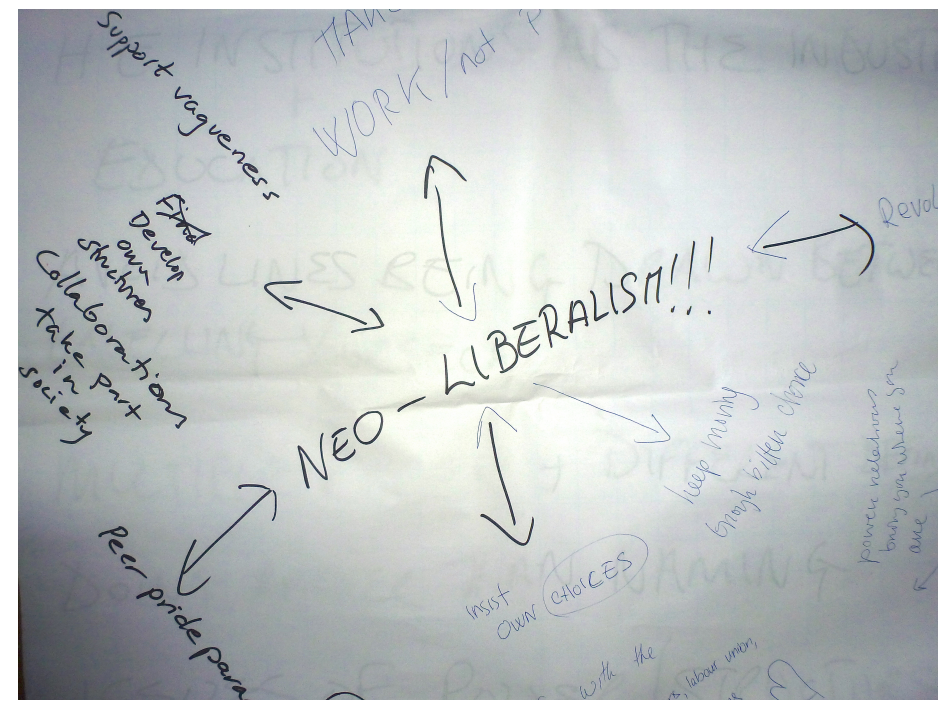

Figure 5: anonymous participant 2014
The emergent themes of community and 'togetherness' (Burrows 2015) were prevalent in the notion of a horizontal as opposed to a vertical exchange, which is identified as both a current and recommended collective practice. For example, having the appropriate time for dialogue with peers creates a horizontal or more circular way of exchange. This could enable time for meeting and 'supporting each other in what we are all trying to do' (Anon. 2014) and thus create a supportive, connected community. The notion of resisting prescribed roles, and doing and taking what one needs was identified by one participant who suggested that 'buying time is what we need metaphorically and actually' (Anon. 2014). Various initiatives exist that 
encourage this sense of community and attract participants from both academic and professional sectors. Groundswell ${ }^{7}$ is one such event that is designed to be an open gathering at which participants talk, listen and share experiences and practices. It is open to all and underpinned by the idea that new conversation has the power to be generative (Groundswell). One of Groundswell's fundamental questions is 'How can we usefully find community and communication across different areas, forms, practices, and applications of dance'?

(Groundswell) and this reflects a sense of community and emphasis on public shared concerns that sit in direct conflict with the neo-liberal market-driven structures that uphold individualism.

This conflict, we suggest, is key in the emergent issues of resistance, insistence and dissidence that arose from round table discussions. The common traits and qualities of the dance artist as adaptable, inventive and maverick could be conceived as entrepreneurial in the competitive marketplace and were cited as ways of operating under the radar to make things happen as desired. As one participant observed 'you can become quite creative in a stealthy way if you call it something else. By our nature we are adaptable, pliable about how you make things happen. That will always be the case' (Anon. 2014).

Being subversively generous in one's everyday practice and exchange with others is a simple but potent suggestion in challenging the power structures that prevail. Nonetheless, the notion of risk taking and ideology of resisting the powers that has its implications and realities to navigate, but the notion of personal agency prevails as a recurrent commentary in making change happen from a grass roots' level in a vertical hierarchy. Personal agency is 
cited as a way of facilitating and questioning how dialogue is possible within the institution/s that can engender a bigger and more visible sense of community, and the subversiveness of being generous is a means of achieving this sense of community.

\section{Epistemology of dance practices}

Across several round table discussions the visual arts were cited in comparison to dance in order to exemplify the differences and subsequent challenges that face dance as an art form in twenty-first-century Britain. Dance does not necessarily produce an artefact (that may rise subsequently in value) as is the case in the visual arts and therefore this poses challenges for those involved in dance-making practices to define and articulate, what exactly, creative dance practices might be and have to offer.

The focus is on something that is produced, a saleable product that makes it difficult for those who are making dances. (Anon. 2014)

Key questions were raised about the epistemology of dance practices and of the hybrid artist-academic, such as, what are we offering? How do we value, articulate or measure what we are offering? Again, it is useful to note the differentiation between the terms 'producing' and 'offering' suggesting a reconsideration of current engagement with artistic practice in alignment with the disparity of how art making practices sit within a production/consumption model. 
Commentaries centre on how offerings or research outputs might sit within institutional frameworks and what the currency and validity of offerings are within these: 'there needs to be a consciousness about what we are offering, not producing, that can be recognised' (Anon 2014). For instance, the Academy’s Research Excellence Framework's (REF) emphasis on impact and end product as a research output can be argued to be at odds with creative practice that is not best measured in this way. Indeed, Greenfield poses pertinent questions that ask artist-academics to consider why they are making work: is it to get it in the public realm and tour it, or is it because it is part of their ongoing practice, enquiry and research? (2015). She goes on to question whether the work is designed to be made public or whether it remains in the studio (2015). It is evident that the demand created by the REF to measure impact 'drives outcomes over other [processes that are] not necessarily the ones that artists are leading or involved in' (Anon. 2014).

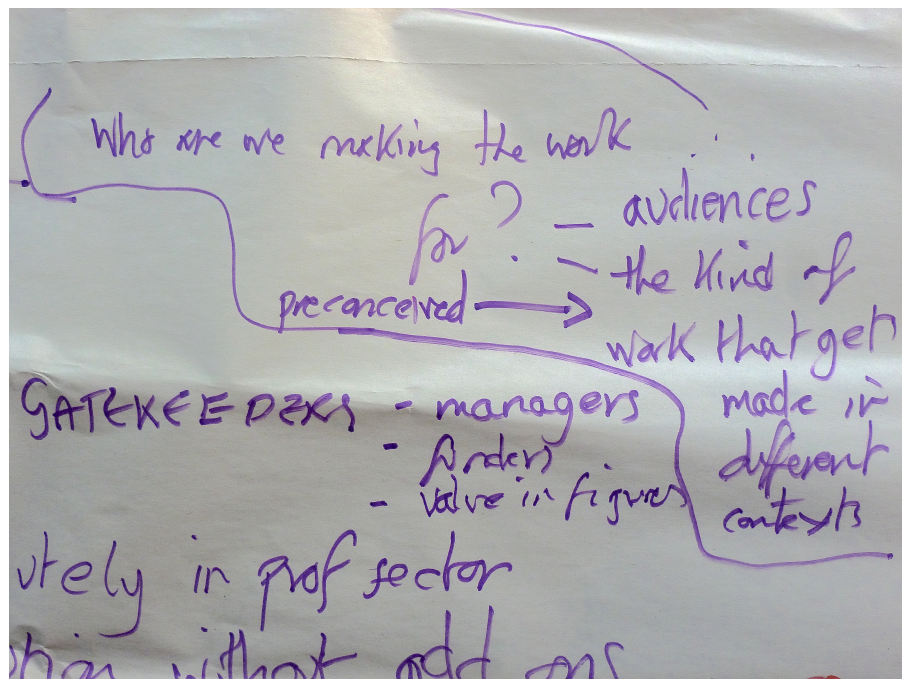

Figure 6: Anonymous participant 2014 
[There is a] need for a 'product' [that is] part of the current political/economical situation in Britain at the moment where there's a move towards Universities as professional academies. (Anon. 2014)

Knowledge production within dance and the epistemology of the creative practitioner are being questioned in terms of the shift in landscape to that of a more neoliberal model entering HE. In his article, 'Bare pedagogy and the scourge of neoliberalism: Rethinking Higher Education as a democratic public sphere', Henry Giroux states:

A new form of bare pedagogy is emerging in higher education focused on market-driven competitiveness and even militaristic goal-setting, while critical pedagogy, with its emphasis on the hard work of critical analysis, moral judgments, and social responsibility (critical pedagogy that goes to the very heart of what it means to address real inequalities of power among faculty and administrators) withers. (2010: 184)

The disparity between market-driven competitiveness and goal setting, and critical and social engagement as cited by Giroux emphasizes the tension in what artistacademics are actually engaged in ( $\mathrm{PaR} /$ creative / pedagogic practices) and what is demanded of them within Academy structures. This disparity is further heightened because of the need for outcome/product which sits in contrast with practices that operate in less quantifiable ways and that seem to contradict the product orientation of the vertical hierarchies in operation. 
Issues of impact were cited as parallel concerns functioning in both academic and professional arts contexts. Impact in the professional arts sector was discussed in terms of audience numbers, project evaluation, issues of diversity and how creative practice addresses the ACE focus of 'great art and culture for everyone' (ACE [2010] 2013). Impact in reference to the REF and its need for evidence and documentation brings challenges to the subject of dance that is not necessarily best quantified in such a manner and raises pertinent questions within a subject that is at odds with traditionally accepted norms of how research is conceived. There is a striving for quantifiable, measurable evaluation and evidence of impact across both the professional arts sector and HE to validate art-making practices within institutional terms, but how can the evidence be evidenced in dance? Again, there is a disparity that exists as there is 'a difference between the evidence of the work and the work itself' (Anon. 2014).

Round table participants suggested that hybrid artist-academics can be empowered by recognizing and reconsidering notions of impact on their own terms. A useful place from which to look for solutions is at the intersection of the two worlds of the Academy and professional arts sector (Anon. 2014). This could involve a reconsideration of language used by artists-academics to articulate their practices. For example, the acknowledgement of the 'transmission' (Anon. 2014) of knowledge or practice, as opposed to the impact of what one does in artistic or pedagogic contexts and how this radiates outwards, under the radar perhaps, in softer, less end-goal-orientated ways can go some way to deepen understanding and perception. 


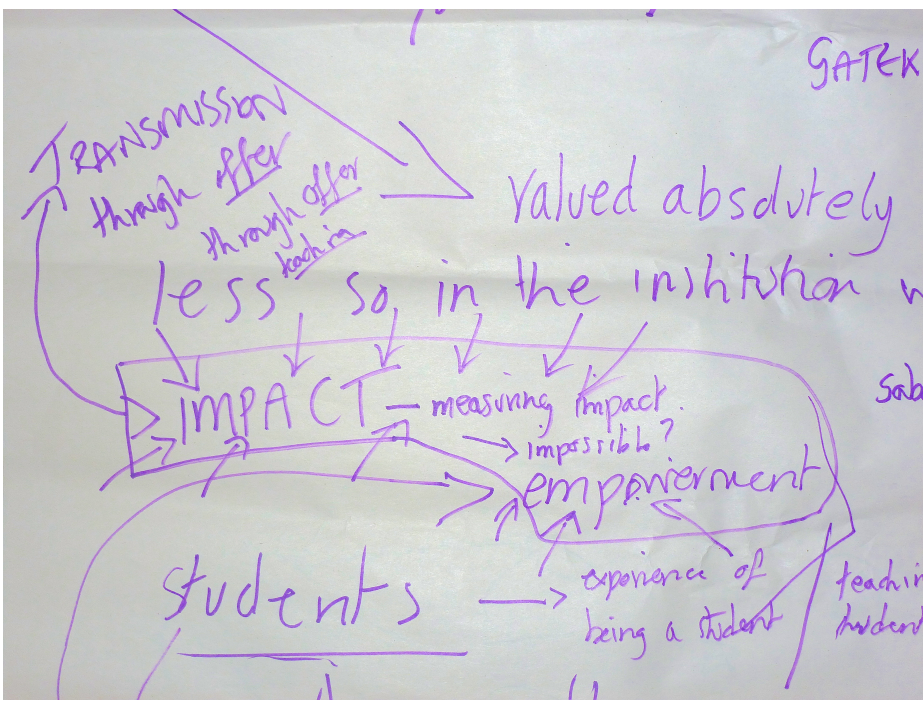

Figure 7: anonymous participant 2014
As cited earlier, the role of

language in this research project

was problematic in various

ways: in researching

terminology adopted in the

wider context; in the

articulation and discussion of

the role of the hybrid artist-

academic and, specifically for

round table participants, in identifying and discussing their own perspectives on the topic.

The role of positive language in articulating what one does was raised as a means of bringing the experiences of being in the Academy and the professional arts sector together and as one participant noted, 'positive language can help to recognise the potential trajectories within both contexts that interweave and focus on those potentials rather than focusing on the way in which those trajectories might limit' (Anon 2014). The idea of personal agency and subversive generosity was raised again as a means of engaging in such approaches to positive languaging.

It's a question of discourse. We, as choreographers/
makers/ dancers, are producing a kind of knowledge/
skills that has value but where is the discourse that
enables us to articulate this kind of knowledge and get
recognition for this kind of knowledge? There are




certain ideas in the Academy that decide what kinds of
knowledge are recognised as academic knowledge,
such as PhDs. So it asks the question, can we find
different discourses/ ways to articulate this specific
kind of knowledge as practitioners? (Anon. 2014)

Different languages and modes of discourse are evolving that are more purposeful. Initiatives such as Groundswell and the Dance HE conference Resilience: Articulating 'Knowledges' Through Dance in the $21^{\text {st }}$ Century (2015) seek to encourage and support ways in which to articulate the kinds of embodied knowledges that dance can generate. For example, at the DanceHE conference (2015) Katye Coe refers to her 'insistent practice' as opposed to her practice led research and that some projects she is involved in outside of academia 'rely on the unknowing being valued' (2015).

\section{Conclusion}

Interim findings so far conform to the notion of a binary between the Academy and the professional arts sector, which has been referred to as 'two separate cultural worlds' (Shreeve 2011: 80). We propose that the liminal space occupied by the hybrid dance artist-academic who works in multiple and fluid ways has helped to identify tensions and synergies. Arising from this, questions and potentialities to do with how the binary of these two cultural worlds can be collapsed by hybrid artist-academics themselves are raised through notions of personal agency, going under the radar and subversive generosity. 
Sir Peter Bazalgette observes that 'to deliver the most exciting, inspirational and, yes, excellent, art for everyone we must draw on the best talent from every part of our country, and think about every aspect of our work, and how it is all interrelated' (2014). The interrelationship that Bazalgette alludes to here can surely include work that is being developed by colleagues working across both academia and the professional arts sector. Given the findings that have evolved from this research project to date, there is evidently much scope for further synergy to evolve between the frameworks of these two sectors, but what has been most prominent in the focus of this research project is that the personal experiences of hybrid dance artist-academics navigating these structures, as opposed to a focus on the PaR / creative practice alone, can illuminate ways forward. It is evident that the common migration of artists into academia allows them to maintain a multi-faceted career (Greenfield 2015) and that this is a pattern that is not so commonly reflected in the reverse direction. She goes on to question whether this one-way migration is because academics are happy to stay in the Academy or whether they find it difficult to get their work accepted by programmers (2015).

This research project is still at a relatively early stage, but we anticipate that as it progresses we will be able to gather more concrete experiences from artist-academics that address some of these questions in order to develop a much more detailed picture of the experiences from across the sectors. We hope to be in a position to make recommendations to help shape more positively the experiences of the hybrid dance artist-academic in 21st Britain. 


\section{References}

Anon. (2003), 'Plenary feedback', PARIP National Conference, Conference Group Two,

Bristol, 14 September, http://www.bris.ac.uk/parip/plenmin_14sept03.htm. Accessed 2

December 2014.

(2014), participant feedback, Questioning the Contemporary in 21st Century British

Dance Practices Symposium Round Table, Leeds Metropolitan University, Leeds, 18 July.

Arts Council, England (ACE) ([2010] 2013), Great Art and Culture for Everyone.

http://www.artscouncil.org.uk/sites/default/files/download-

file/Great $\% 20$ art $\% 20$ and $\% 20$ culture $\% 20$ for $\% 20$ everyone.pdf. Accessed 4 December 2014.

Bailie, P. (2003), 'Plenary Feedback', PARIP National Conference, Conference Group

Two, Bristol, 12 September, http://www.bris.ac.uk/parip/plenmin_12sept03.htm.

Accessed 2 December 2014.

Bannerman, C. (2003), 'Advisory Group Summary', PARIP National Conference,

Bristol, 14 September, http://www.bris.ac.uk/parip/agfdbk_14sept03.htm. Accessed 2

December 2014.

Barrett, E. and Bolt, B. (eds) (2014), Practice as Research, Approaches to Creative Arts 
Enquiry, London: I. B. Tauris.

Bazalgette, P. (2014), 'Arts council and the creative case for diversity', http://www.artscouncil.org.uk/what-we-do/our-priorities-2011-15/diversity-and-creativecase/. Accessed 12 December 2014.

Bock, F. (2015), ‘A Conversation Place \#5: The dual identity of the hybrid dance artistacademic: Synergies, tensions and opportunities', Dance4 Nottdance Festival, https://www.youtube.com/watch?v=Rj9HDFgR7ts. Accessed 5 June 2015.

Burrows, J. (2015), 'Keynote address', DanceHE conference, Resilience: Articulating Dance 'Knowledges' in the 21st Century, De Montfort University, Leicester, 9 April.

Coe, K. (2015), 'Considering research informed teaching', Resilience: Articulating Dance 'Knowledges' in the 21st Century, De Montfort University, Leicester, 9 April.

Daichendt, G. (2011), Artist Scholar: Reflections on Writing and Research, Chicago: Intellect Publishers.

Daniel, H. (2010), 'Writing dance in the age of technology: Towards transdisciplinary discourse', Forum for Modern Language Studies, 46:4, p. 460.

Foster et al. (2011), 'Gatekeeper search and selection strategies: Relational and network governance in a cultural market', Poetics, 39:4 pp. 247-65.

Giroux, H. A. (2010), 'Bare pedagogy and the scourge of neoliberalism: Rethinking 
Higher Education as a democratic public sphere', The Educational Forum, 74:3, pp. 18496.

Greenfield, J. (2015), 'A Conversation Place \#5: The dual identity of the hybrid dance artist-academic: Synergies, tensions and opportunities', Dance4 Nottdance Festival, https://www.youtube.com/watch?v=Rj9HDFgR7ts. Accessed 5 June 2015.

Groundswell (n.d.), http://www.independentdance.co.uk/programmepage/exchanges/groundswell/. Accessed 5 June 2015.

Hicks, C. (2014), 'Keynote address', Questioning the Contemporary in $21^{\text {st }}$ Century British Dance Practices Symposium, Leeds Metropolitan University, Leeds, 18 July.

HEFCE (2008), 'News and archive', http://www.hefce.ac.uk/news/newsarchive/2008/news62116.html. Accessed 2 November 2014.

Hewson, R. (2014), Cultural Capital: The Rise and Fall of 'Creative Britain', London: Verso books.

Huxley, M. (2015), The Dancer's World 1920-1945: Modern Dancers and Their Practices Reconsidered, Andover: Palgrave Macmillan. 
Kapur, J. (2011), 'Capital limits on creativity: Neoliberalism and its uses of art', Jump Cut: A Review of Contemporary Media Jump Cut, 53.

.http://www.ejumpcut.org/archive/jc53.2011/KapurCreativeIndus/index.html. Accessed 4 December 2014.

Maxwell, J. (2008), 'Designing a qualitative study' in Bickman. L and D.J. Rog (eds), Handbook of Applied Social Research Methods, Thousand Oaks: SAGE Publications, http://corwin.com/upm-data/23772_Ch7.pdf. Accessed 15 October 2013.

Nelson, R. (2013), Practice as Research in the Arts, Basingstoke: Palgrave Macmillan.

O’Toole, J. (2006), Doing Drama Research, Stepping into Enquiry in Drama, Theatre and Education, City East, QLD, Drama Australia.

PARIP (2003), 'Overview', http://www.bris.ac.uk/parip/introduction.htm. Accessed 2 December 2014. (2003), 'PARIP 2003', http://www.bris.ac.uk/parip/sept2003.htm. Accessed 2 December 2014.

Piccinni, A. and Kershaw, B. (2004), 'Practice-as-research in performance: From epistemology to evaluation', Digital Creativity, 15:2, pp. 86-92. 
REF2014 (2013), 'Expert panels',

http://www.ref.ac.uk/panels/assessmentcriteriaandleveldefinitions/. Accessed 7

December 2014.

ResCen (n.d.), 'Home', http://www.rescen.net/home.html\#.VIsgVCjDsso. Accessed 2

December 2014.

Reynolds, P. (2003), 'Plenary Feedback', Conference Group Three, 13 September, http://www.bris.ac.uk/parip/plenmin_13sept03.htm. Accessed 2 December 2014.

Shreeve, A. (2011), 'Being in two camps: Conflicting experiences of practice based academics', Studies in Continuing Education, 33:1, pp. 79-91.

Strauss, A. (1987), Qualitative Analysis for Social Scientists, Cambridge: Cambridge University Press.

Strauss, A. and Corbin, J. (1990), Basics of Qualitative Research, Grounded Theory Procedures and Techniques, London: Sage Publishers.

Tondeur, L. (2013), in Reisz, M., 'Blurring the lines between art and research'. The Times Higher Education. http://www.timeshighereducation.co.uk/features/blurring-thelines-between-art-and-research/3/2002260.article. Accessed 2 November 2013. 
The World Café Community (n.d.), 'Who we are', http://www.theworldcafe.com/method.html. Accessed 17 November 2013.

\section{Contributor details}

Sally Doughty has been making and performing work internationally since the early 1990s, working with many leading British choreographers including Laurie Booth, Sue MacLennan and Rosemary Lee. Her key area of research focuses on improvisation practices, which informs her performance and writing. In 2011 she commissioned a solo, I Think Not from Deborah Hay, which has been performed in Estonia, Philadelphia and United Kingdom, and she has contributed a book chapter based on her work with Hay due for publication 2015/2016. She is a core member of Quick Shifts improvisation collective. She recently represented the United Kingdom in an online conversation with improvisers from Australia and India and is co-researcher in a project that investigates the identity of hybrid dance artist-academics working across academia and the professional arts sector. Sally is Principal Lecturer in Dance at De Montfort University, Leicester, where she is Programme Leader for the M.A. Performance Practices and M.A. Arts.

Marie Fitzpatrick is a senior lecturer in dance at De Montfort University where she teaches undergraduate and postgraduate courses in Dance and Performing Arts. Her research interests include spatial practices and intermedial/interdisciplinary choreographic practices and forms. Her work focuses on the relationship between body, space and environment and how innovative choreographic practice and ideas in relation to embodiment can be used as an investigative tool within a wider context. An article 
about her Practice-as-Research making processes was published in the Journal of Dance and Somatic Practices (2014). Marie has worked extensively as an independent dance artist in the United Kingdom and internationally since 1994 and has worked with Fin Walker, Reckless Sleepers Theatre Company, New Art Club and Bedlam Dance Company amongst others. Marie was also the co-founder and Chair of Force 5, an artistled organization supporting the professional development of mid-career artists (19992005).

\section{Contact:}

De Montfort University, The Gateway, Leicester, LE1 9BH, UK.

E-mail: sdoughty@dmu.ac.uk

E-mail:mfitzpatrick@dmu.ac.uk

Notes:

\footnotetext{
${ }^{1}$ Held at The Artez Institute, Arnhem, the Netherlands, 2-3 December 2013. See http://www4.artez.nl/mocblog/inventing-futures/.

2 Held at Leeds Metropolitan University and Yorkshire Dance, 18 July 2014, see http://www.yorkshiredance.com/whatson/questioning-the-contemporary.

3 Held at Independent Dance, London, 17 September 2014.

${ }^{4}$ See https://www.youtube.com/watch?v=Rj9HDFgR7ts.

5 The separation between education and professional practice was addressed in the United Kingdom at a series of conferences organized by NATFHE Dance Section (forerunner of SCODHE and then DanceHE) in the mid-1970s that brought together artists and administrators from The Place in London and those working in colleges and universities. At the 1975 symposium, Dance in Higher Education: A Look Ahead, a pivotal discussion took place about the relationship between the professional contemporary dance artist and the higher education lecturer and it was here that the stark distinction between the professional dancer and the educationist was elucidated and debated.

${ }^{6}$ All references to 'Anon. 2014' from here on indicate feedback gathered from participants from the project's roundtable discussions.

7 See http://www.independentdance.co.uk/programmepage/exchanges/groundswell/.
} 